\title{
Recurrent hemifacial oedema
}

\author{
Mariana Miranda, ${ }^{1}$ Nádia Santos, ${ }^{1}$ Susana Gomes, ${ }^{1}$ Cláudia Constantino ${ }^{2}$
}

${ }^{1}$ Pediatric Department, Hospital do Espírito Santo EPE, Evora, Portugal

${ }^{2}$ Pediatric Oncology, Instituto Português de Oncologia de Lisboa Francisco Gentil EPE, Lisboa, Lisboa, Portugal

\section{Correspondence to}

Dr Mariana Miranda, mariana f_miranda@hotmail.com

Accepted 3 June 2017

\section{DESCRIPTION}

A 3-year-old boy, with no relevant family/personal history, presented at the emergency department due to recurrent left hemifacial erythematous oedema and feverish peak. The mother reported two similar episodes in the previous months, interpreted as periorbital cellulitis, with resolution with systemic antibiotic and oral corticosteroid. She denied fever, weight loss or other constitutional symptoms.

At examination presented skin paleness; soft, non-tender swelling and erythema of the left periorbital region (Figures 1); shotty, non-tender, well defined, smooth generalised lymphadenopathy (cervical, submaxillary, axillary, inguinal); firm and non-tender splenomegaly palpable $2 \mathrm{~cm}$ below the costal margin. Ophthalmological examination and funduscopy were normal.

Laboratory tests revealed a normocytic and normochromic anaemia (haemoglobin of $8.4 \mathrm{~g} /$ $\mathrm{dL})$, leucocytosis $(28100 \mathrm{WBC} / \mu \mathrm{L})$ with $77 \%$ of lymphocytes, $137.000 / \mu \mathrm{L}$ platelets, normal liver function enzymes and negative serology for EpsteinBarr virus. Peripheral blood smear revealed 44\% of blasts; flow cytometry was compatible with B cell acute lymphoblastic leukaemia (ALL). Abdominal

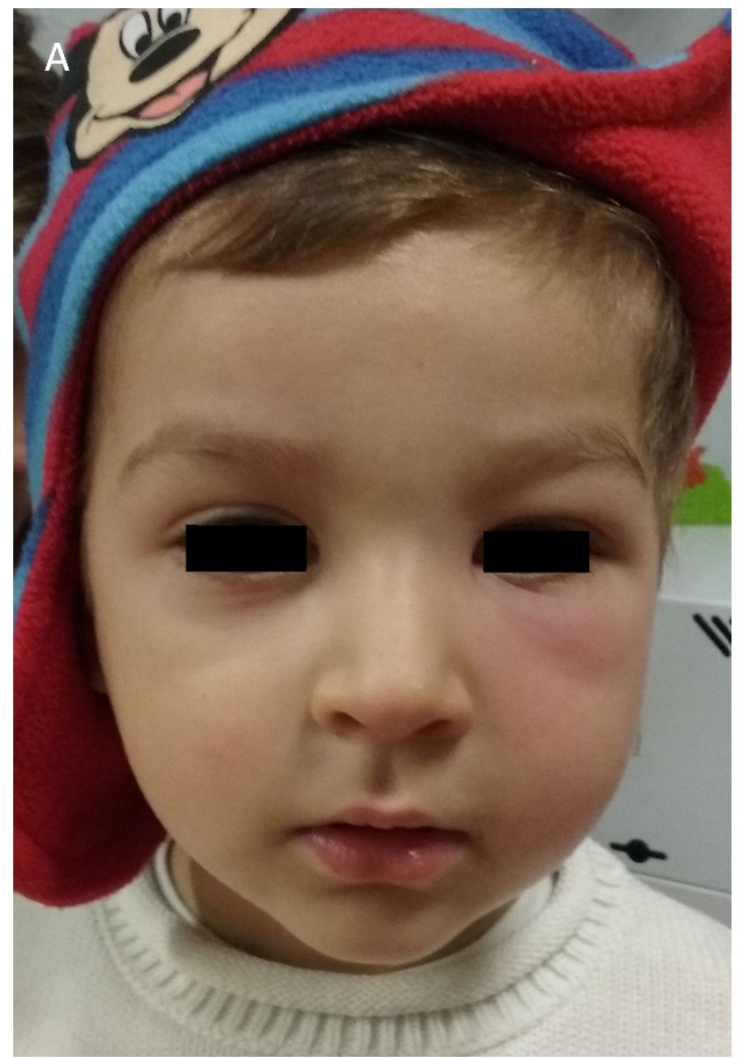

ultrasound identified homogeneous hepatosplenomegaly and visceral lymphadenopathies; chest X-ray was normal.

Ophthalmological and periorbital manifestations have been frequently reported during the evolution of ALL (as much as 90\%), either by leukaemic infiltration or secondary to haematological derangements (such as anaemia, thrombocytopenia, leucopenia and hyperviscosity). ${ }^{12}$ Recurrent hemifacial oedema has not been described as a presenting symptom of ALL; however, it has been reported in the superior vena cava syndrome. ${ }^{3}$ We hypothesise that the unilateral and fluctuating character of the oedema may have been related to lymph node compression of peripheral lymphatic or vascular structures. Corticosteroid treatment might have contributed to the transient remission in the previous episodes.

Contributors MM: bibliographic research, data collection, analysis and interpretation of data and main role in writing the manuscript, and approval of the final version of the article. NS: writing the manuscript and approval of the final version of the article. SG and CC: substantial intellectual contribution, participation in the analysis and interpretation of data, critical review of content and approval of the final version of the article.

Competing interests None declared.

\section{(1) \\ CrossMark}

\section{To cite: Miranda M} Santos N, Gomes S, et al. BM Case Rep Published Online First: [please include Day Month Year]. doi:10.1136/ bcr-2017-220523

Figure 1. Oedema and erythema of the left periorbital region.

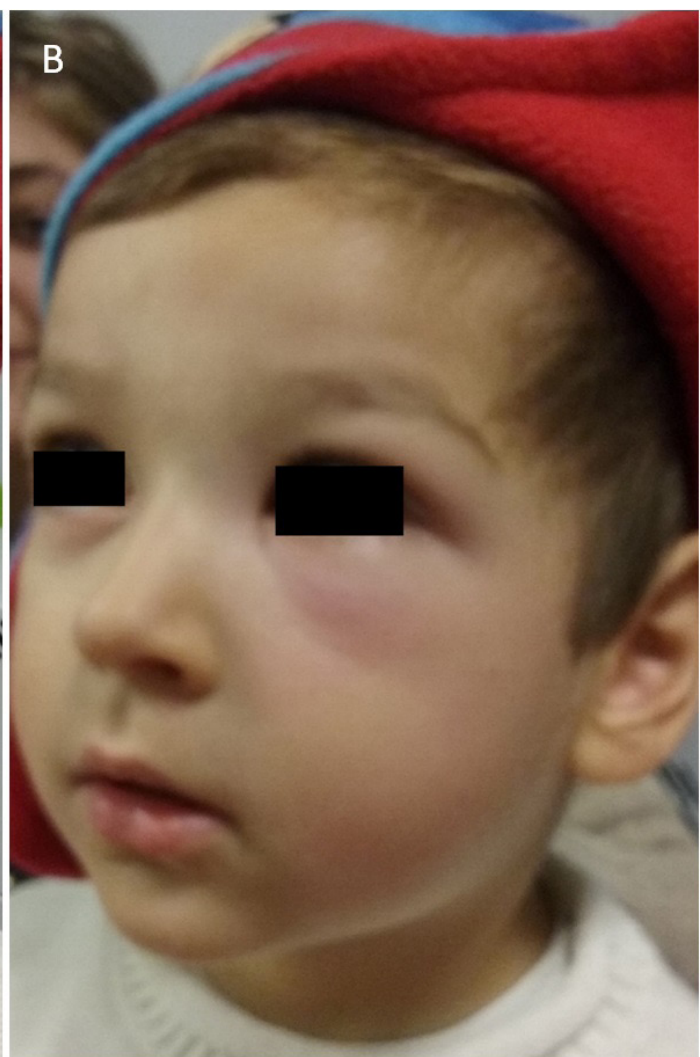




\section{Learning points}

- The presenting symptoms of paediatric cancer are often non-specific and may be difficult to distinguish from common and self-limiting childhood illnesses.

- Recurrent hemifacial oedema, although not a common manifestation ofacute lymphoblastic leukaemia was the presenting sign of the disease in this case.

Patient consent Obtained from guardian.

Provenance and peer review Not commissioned; externally peer reviewed. (c) BMJ Publishing Group Ltd (unless otherwise stated in the text of the article) 2017. All rights reserved. No commercial use is permitted unless otherwise expressly granted.

\section{REFERENCES}

1. Mateo J, Ascaso FJ, Núñez E, et al. phthalmological Manifestations in Acute Lymphoblastic Leukemia. Faderl S, ed. Novel Aspects in Acute Lymphoblastic Leukemia: InTech, 2011. ISBN: 978-953-307-753-6. http://www.intechopen.com/books/novelaspects-in-acute-lymphoblastic-leukemia/ophthalmologicalmanifestations-in-acutelymphoblastic-leukemia.

2 Orhan B, Malbora B, Akça Bayar S, Bayar SA, et al. Ophthalmologic findings in children with leukemia: a Single-Center Study. Turk J Ophthalmol 2016;46:62-7.

3. Gupta V, Ambati SR, Pant P, et al. Superior vena cava syndrome in children. Indian J Hematol Blood Transfus 2008;24:28-30.

Copyright 2017 BMJ Publishing Group. All rights reserved. For permission to reuse any of this content visit

http://group.bmj.com/group/rights-licensing/permissions.

BMJ Case Report Fellows may re-use this article for personal use and teaching without any further permission.

Become a Fellow of BMJ Case Reports today and you can:

- Submit as many cases as you like

- Enjoy fast sympathetic peer review and rapid publication of accepted articles

- Access all the published articles

- Re-use any of the published material for personal use and teaching without further permission

For information on Institutional Fellowships contact consortiasales@bmjgroup.com

Visit casereports.bmj.com for more articles like this and to become a Fellow 